\title{
Endogenous Opioid Modulation of Pancreatic Hormone Secretion: Studies in Dogs
}

\author{
Ellis R. Levin, Tadataka Yamada, Seymour Levin, and Steven Mills
}

\begin{abstract}
The role of endogenous opioid peptides in the modulation of secretion of hormones from the endocrine pancreas was studied in dogs. In response to insulin-induced hypoglycemia, plasma glucagon secretion significantly increased, followed by an increase in plasma somatostatin immunoreactivity. Pretreatment with the opiate antagonist, naloxone, prevented the somatostatin response but had no effect on the augmented glucagon secretion. Neither the degree of hypoglycemia nor recovery from the induced glucose nadir were affected by naloxone. Arginine Hcl administration resulted in prompt increases in immunoreactive glucagon and insulin secretion, as well as a rise in serum glucose. Pretreatment with naloxone failed to affect any of these responses. Our results suggest that endogenous opioid peptides mediate the somatostatin response following hypoglycemia-induced glucagon secretion.
\end{abstract}

(- 1986 by Grune \& Stratton, Inc.

$\mathbf{E}$ NDOGENOUS opioid peptides have been localized in the islets of Langerhans in rats, ${ }^{1.2}$ inspiring a number of studies of the effects of these peptides on hormone secretion from the endocrine pancreas. In vitro perfusion studies in dogs and rats $^{3-5}$ have demonstrated that $\mu$-receptor active opiates $\beta$-endorphin and morphine stimulate insulin and glucagon secretion while $\delta$-receptor active opioids met and leu-enkephalin inhibit insulin and glucagon release. Thus, opiates acting at different receptors may have opposite actions on the pancreas. Studies in vivo have shown that administration of pharmacologic doses of $\beta$-endorphin increase plasma glucagon, insulin, and glucose in humans. ${ }^{6,7}$ Similar effects occur after the administration of exorphins, dietary proteins with opiate-like activity. ${ }^{8}$ Whether endogenous opioid peptides modulate the endocrine pancreas response to secretagogues, including physiologic stimuli, has not been extensively studied. We, therefore, examined the secretion of glucagon and somatostatin immunoreactivity (SI) and the recovery of blood glucose after insulin-induced hypoglycemia while antagonizing endogenous opioid action. Further, we characterized the insulin, glucagon, glucose, and SI responses to arginine injection and determined whether endogenous opioid peptides modify the hormonal response to this pancreatic secretagogue in dogs.

\section{MATERIALS AND METHODS}

Seven mongrel dogs, six male and one nonpregnant female, 18-25 $\mathrm{kg}$, were adapted to light harness restraint. The dogs were maintained on Wayne Pro-Mix (Gardena, Calif). After an overnight fast. each dog underwent four separate sessions, studies beginning at approximately $0800 \mathrm{~h}$ each day, one to four days apart. Indwelling butterfly needles were inserted into a hind leg vein, kept patent with heparinized saline for drug administration and blood drawing. A 45-minute equilibration period postneedle insertion preceded all experiments. In the first experiment, $10 \mathrm{~mL}$ of blood was withdrawn at -15 and -1 minute for determination of serum glucose and insulin, plasma glucagon, and somatostatin immunoreactivity. At time 0 , arginine $\mathrm{Hcl} 12.5 \mathrm{mmol}$ was administered as an IV bolus over
2 minutes and blood was withdrawn at $4,7,10,15$, and 30 minutes after arginine for hormone measurement. This protocol was similar to previous studies of arginine stimulation of the pancreas. ${ }^{9}$ After each blood sampling, an equal volume of saline was injected. Blood for glucagon was collected in ice-cold syringes, rapidly injected into test tubes containing benzamidine, and EDTA and cold centrifuged within 30 minutes, plasma frozen at $-70^{\circ} \mathrm{C}$ for subsequent assay. Blood for somatostatin was injected into tubes containing trasylol (2000 units $/ 2 \mathrm{~mL}$ ) and EDTA and processed similarly to glucagon.

During the second session, blood was withdrawn at -46 minutes at which time naloxone $190 \mathrm{nmol} / \mathrm{kg}$ was given as an IV bolus. Blood for hormone measurements was then withdrawn at -15 and -1 minutes; arginine $12.5 \mathrm{mmol}$ and naloxone $190 \mathrm{nmol} / \mathrm{kg}$ again was given at time 0 and blood withdrawn at times identical to the arginine alone experiment.

The third session examined the effects of insulin-induced hypoglycemia on blood glucose, plasma glucagon, and SI. Baseline hormone measurements were made at -15 and -1 minutes; at time 0 , pork regular insulin 0.1 units $/ \mathrm{kg}$ was administered and blood sampled at $+15,+30,+45,+60,+75$, and +90 minutes. During the fourth session, blood was withdrawn at -46 minutes and naloxone was given IV. Blood was then sampled at $-30,-15$, and -1 minutes. At time 0 , insulin 0.1 units $/ \mathrm{kg}$ and raloxone $190 \mathrm{nmol} / \mathrm{kg}$ were administered and blood sampled identically to the insulin alone protocol. Serum glucose was determined by glucose oxidase method with a Beckman glucose analyzer. Immunoreactive insulin ${ }^{10}$ and glucagon ${ }^{11}$ were determincd by radioimmunoassay, glucagon measurements utilizing $30 \mathrm{~K}$ antiserum (Unger). Plasma somatostatinlike immunoreactivity was determined as previously described. ${ }^{12.13}$ The raised antibody to somatostatin is directed against the central portion of the molecule (positions 4-13). All response data were compared by analysis of variance and student's t-test. $P<0.05$ was considered significant.

From the Departments of Medicine, Veterans Administration Medical Centers Long Beach and Wadsworth, and the University of California at Irvine and Los Angeles; and University of Michigan Ann Arbor.

Supported in part by the Research Service of the Veterans Administration and NIH Grants AM21031 and AM33500.

Address reprint requests to Ellis $R$. Levin, MD. Department of Medicine, VA Medical Center Long Beach, 5901 E. 7 th St, Long Beach. CA 90822 .

(C) 1986 by Grune \& Stratton, Inc. 0026-0495/86/3501-0010\$03.00/0 


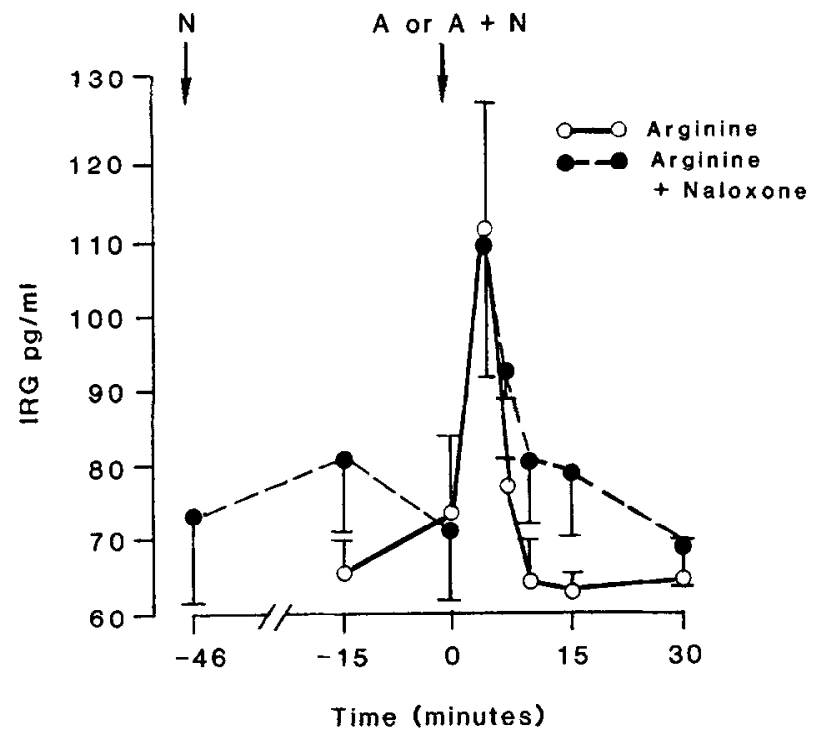

Fig 1. Plasma immunoreactive glucagon response to arginine $12.5 \mathrm{mmol}$ or arginine and naloxone $190 \mathrm{nmol} / \mathrm{kg}$ in dogs. Each point is the mean \pm SEM $\{n=7$ ).

\section{RESULTS}

\section{Arginine Studies}

Arginine administration resulted in a marked increase in plasma glucagon immunoreactivity (mean basal IRG $73.7 \pm 8.4[\mathrm{SE}] \mathrm{pg} / \mathrm{mL}$, mean peak IRG at $4 \mathrm{~min}$ after argininc $112 \pm 20.6[\mathrm{SE}] \mathrm{pg} / \mathrm{mL}, P<$ 0.05 ; Fig 1). Naloxone pretreatment had essentially no effect on basal glucagon secretion and failed to significantly affect the peak or total glucagon response to arginine (mean prenaloxone baseline IRG 74.3 \pm 13.4 [SE] $\mathrm{pg} / \mathrm{mL}$, mean postnaloxone, prearginine baseline IRG $71.7 \pm 8.9[\mathrm{SE}] \mathrm{pg} / \mathrm{mL}$, mean peak IRG at +4 $\min 110 \pm 18.4[\mathrm{SE}] \mathrm{pg} / \mathrm{mL})$. The variation in peak glucagon response seen with arginine and arginine plus naloxone was mainly due to the marked stimulation of glucagon secretion in one dog. Although the stimulatory effect by arginine on glucagon was greater in the presence of naloxone at several time points, there was no statistically significant difference compared to arginine alone. Plasma insulin secretion was enhanced by arginine administration. Peak levels of insulin were noted 4 minutes after arginine and were significantly increased above baseline (mean basal IRI $13.3 \pm 1.3$

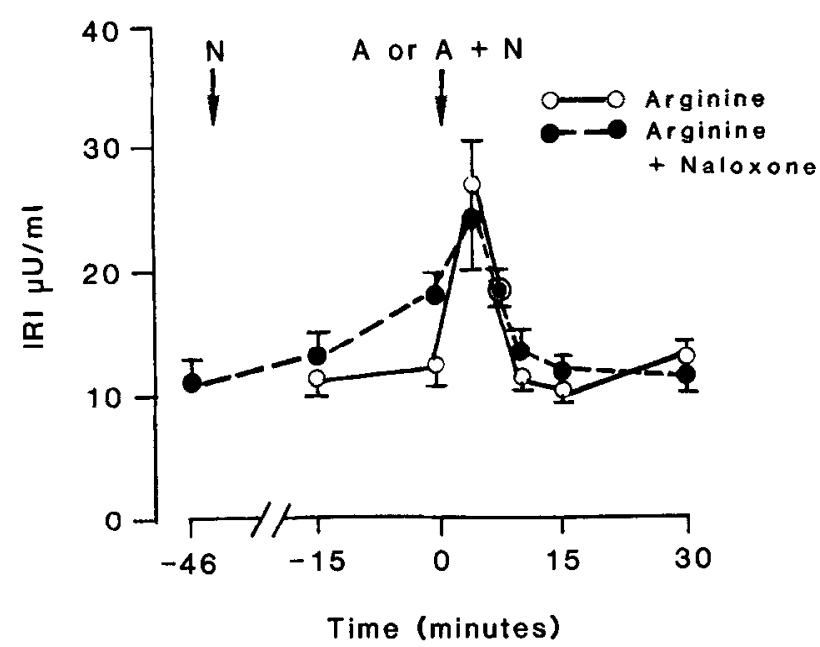

Fig 2. Serum immunoreactive insulin responses to arginine $12.5 \mathrm{mmol}$ or arginine and naloxone $190 \mathrm{nmol} / \mathrm{kg}$ in dogs. Each point represents the mean \pm SEM $(n=7)$.

[SE] $\mu / \mathrm{mL}$, mean peak IRI $27 \pm 4.1 \mu / \mathrm{mL}, P<0.01$; Fig 2). Naloxone administered at -45 minutes resulted in a steady though nonstatistically significant rise in plasma insulin over the subsequent 45 minutes. Due to the higher baseline insulin level after the initial naloxone injection, arginine-stimulated insulin secretion was somewhat attenuated. Nevertheless, the total IRI secretion was still highly significant $(P<$ 0.05 ) and the peak IRI response at +4 minutes was comparable to that seen during the arginine alone experiment. Serum glucose rose significantly following arginine administration (Table 1). The peak glucose response occurred 4 minutes after arginine (mean basal glucose $102 \pm 4.6 \mathrm{mg} / \mathrm{dL}$, mean basal glucose $115 \pm 5.4 \mathrm{mg} / \mathrm{dL}, P<0.05)$ and was not influenced by naloxone (mean prenaloxone baseline glucose $109 \pm$ $5.6 \mathrm{mg} / \mathrm{dL}$, mean peak glucose $122 \pm 10.2 \mathrm{mg} / \mathrm{dL}$ ). Although the mean serum glucose levels after arginine plus naloxone were somewhat higher for 15 minutes compared to arginine alone, there was no significant difference between these two experiments. Plasma somatostatin immunoreactivity was moderately but statistically insignificantly stimulated by arginine. Pretreatment with naloxone had little effect on the SI response to arginine (data not shown).

Table 1. Serum Glucose In Response to Arginine $12.5 \mathrm{mmol}$ or Arginine and Naloxone $190 \mathrm{mmol} / \mathrm{kg}$ in Dogs

\begin{tabular}{|c|c|c|c|c|c|c|c|c|}
\hline \multicolumn{9}{|c|}{ Time (min) } \\
\hline & -46 & -15 & -1 & 4 & 7 & 10 & 15 & 30 \\
\hline Arginine & - & $106 \pm 3.3$ & $102 \pm 4.6$ & $115 \pm 5.4^{*}$ & $109 \pm 3.5$ & $104 \pm 2.7$ & $104 \pm 3.4$ & $106 \pm 5$ \\
\hline Arginine and Naloxone & $103 \pm 5.5$ & $111 \pm 8.8$ & $109 \pm 5.6$ & $122 \pm 10.2^{*}$ & $119 \pm 7.9^{*}$ & $111 \pm 5.4$ & $109 \pm 5.5$ & $103 \pm 4.7$ \\
\hline
\end{tabular}

$* P<0.05$ compared to baseline by ANOVA and student's t-test. Each point represent mean $\pm \mathrm{SEM}(\mathrm{n}=7) \mathrm{in} \mathrm{mg} / \mathrm{dL}$. 
Table 2. Serum Glucose in Response to Insulin $0.1 \mu / \mathrm{kg}$ or Insulin and Naloxone $190 \mathrm{nmol} / \mathrm{kg}$ in Dogs

\begin{tabular}{lcccccccccc}
\hline & \multicolumn{10}{c}{ Time (min) } \\
\hline & -46 & -30 & -15 & -1 & 15 & 30 & 45 & 60 & 75 & 90 \\
\hline Insulin & - & - & $103 \pm 4.8$ & $106 \pm 5.1$ & $50.3 \pm 4.8^{*}$ & $56 \pm 3.5^{*}$ & $66 \pm 6.3^{*}$ & $80 \pm 8.6$ & $88 \pm 9.1$ & $99 \pm 10.1$ \\
Insulin and Naloxone & $102 \pm 3$ & $105 \pm 4.1$ & - & $106 \pm 3.9$ & $53 \pm 4.4^{*}$ & $61 \pm 2.8^{*}$ & $61 \pm 4.5$ & $72 \pm 7.1$ & $84 \pm 6.2$ & $91.1 \pm 5.9$ \\
\hline$* P<0.05$ compared to baseline by ANOVA and student's t-test. Each point represents mean \pm SEM (n $=7$ ) in $\mathrm{mg} / \mathrm{dL}$.
\end{tabular}

\section{Insulin-Induced Hypoglycemia Studies}

Insulin administration resulted in a marked fall of serum glucose (Table 2). Each dog demonstrated a marked biologic effect of insulin, with extreme lethargy occurring in all. The glucose nadir occurred 15 minutes after insulin bolus (mean basal glucose $106 \pm 5[\mathrm{SE}] \mathrm{mg} / \mathrm{dL}$, mean nadir $50.3 \pm 4.8[\mathrm{SE}]$ $\mathrm{mg} / \mathrm{dL}, P<0.01)$ and recovery to near basal levels occurred by 90 minutes. Pretreatment with naloxone failed to affect the degree of insulin-induced hypoglycemia and the glucose recovery course was similar to that following insulin alone. Insulin induced hypoglycemia caused a significant $(P<0.05)$ stimulation of glucagon (mean basal IRG $78.9 \pm 8.4[\mathrm{SE}] \mathrm{pg} / \mathrm{mL}$, mean peak IRG $122 \pm 12[\mathrm{SE}] \mathrm{pg} / \mathrm{mL}$ ) which was seen 15 minutes after the glucose nadir (Fig 3). Naloxone had no effect on basal glucagon levels; similarly, naloxone failed to influence hypoglycemiainduced glucagon secretion (mean basal IRG $73.9 \pm$ $9.9[\mathrm{SE}] \mathrm{pg} / \mathrm{mL}$, mean basal IRG $128 \pm 19$ [SE] $\mathrm{pg} / \mathrm{mL}, P<0.05$ ). Plasma somatostatin immunoreactivity rose significantly after insulin administration, the peak stimulation occurring at 30 minutes postinsu-

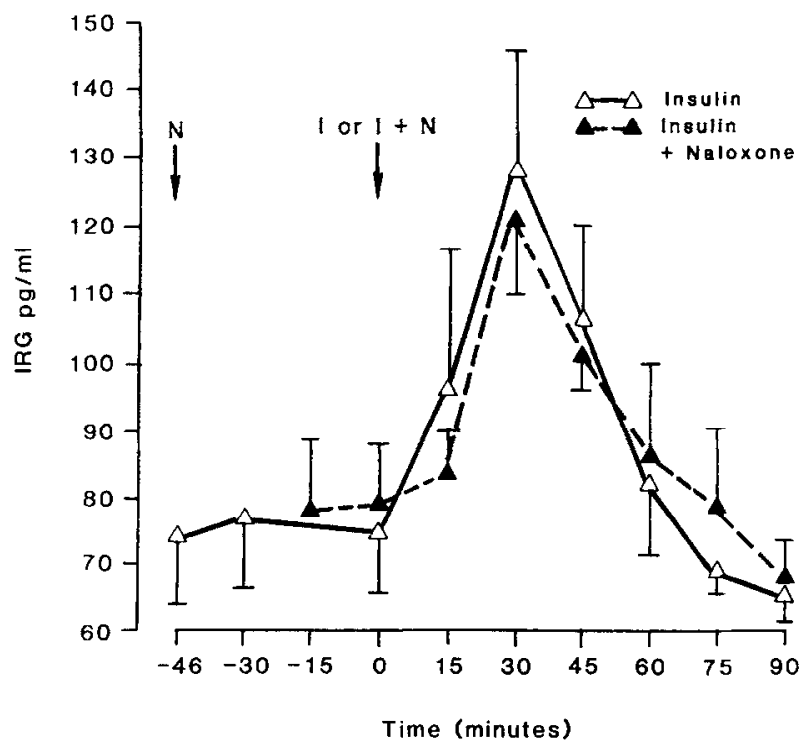

Fig 3. Plesme glucagon immunoreactivity response to insulin $0.1 \mathrm{u} / \mathrm{kg}$ or insulin and naloxone $190 \mathrm{nmol} / \mathrm{kg}$ in dogs. Each point is the mean $\pm \operatorname{SEM}(n=7)$. lin (Fig 4) (basal mean of -30 and -1 time points $28.4 \pm 3[\mathrm{SE}] \mathrm{fmol} / \mathrm{mL}$, mean peak at $+30 \mathrm{~min} 39.1$ \pm 4.2 [SE] $\mathrm{fmol} / \mathrm{mL}, P<0.025$ ). Pretreatment with naloxone caused a modest decrease in plasma SI and blunted the rise in plasma SI after insulin administration.

\section{DISCUSSION}

Many in vitro studies have suggested a role for endogenous opioid peptides in the regulation of hormone secretion from the endocrine pancreas. ${ }^{3-5,14,15}$ Additionally, several in vivo human studies have demonstrated that administration of $\beta$-endorphin in pharmacologic doses ${ }^{6,7}$ increases plasma levels of insulin and glucagon, affecting glucose homeostasis. Few studies have addressed whether well-characterized stimuli to hormone secretion from the endocrine pancreas in vivo act through endogenous opiates. Most important is the response to hypoglycemia. For our experiments, we selected a dose(s) of naloxone that would be expected to antagonize the systemic effects of endogenously secreted opiates. This is important because the site of secretion of endogenous opioid peptides may originate within the brain, ultimately affecting the endocrine pancreas. ${ }^{16-18}$

Arginine $\mathrm{Hcl}$ resulted in rapid increases of serum

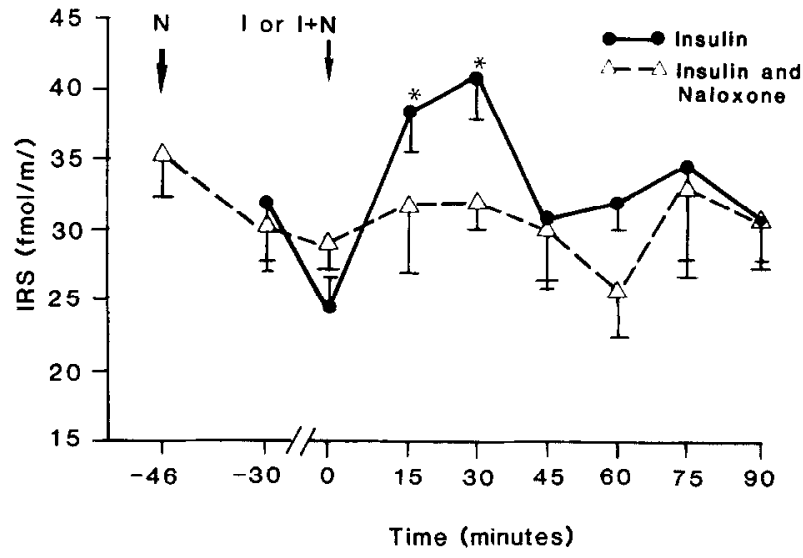

Fig 4. Plasma immunoreactive somatostatin responses to insulin $0.1 \mathrm{u} / \mathrm{kg}$ or insutin and natoxone $190 \mathrm{nmal} / \mathrm{kg}$ in dogs. Each point represents the mean $\pm \operatorname{SEM}(n=6)$. $\bullet P<0.025$ compared to baseline (mean of -30 and -1 time points); $P<0.05$ compared to insulin and naloxone at identical time points. 
glucose, insulin, and glucagon that were not affected by prior treatment with naloxone. Stimulation of the pancreas by this amino acid appears, then, not to be dependent on an opioid thus confirming the results of Morley et $\mathrm{al}^{19}$ who reported similar findngs in humans.

In contrast, we found that endogenous opioid peptides may play a role in the hormone response to hypoglycemia. Following insulin-induced glucopenia, glucagon and somatostatin secretion increased and recovery to normoglycemia ensued. The glucagon response in our dogs was unaffected by pretreatment with the opiate antagonist. Ilowever, the increased somatostatin secretion following hypoglycemia was prevented by naloxone administration. Insulin-induced hypoglycemia has been shown previously to result in the secretion of somatostatin immunoreactivity in humans. ${ }^{20}$ Recently, it has been demonstrated that in dogs administration of $\beta$-casomorphin results in increased plasma somatostatin, ${ }^{21}$ and exorphininduced somatostatin secretion can be inhibited by naloxone. ${ }^{22}$ In vitro studies of the isolated perfused dog pancreas, however, have shown that administered enkephalin decreases pancreatic SI secretion ${ }^{23}$; this may reflect activation of a different $(\delta)$ opiate receptor. It is also conceivable that our measurements of somatostatin reflect a significant contribution from the gastrointestinal tract. ${ }^{24}$ Our findings suggest that in response to hypoglycemia, pancreatic delta cell secretion is dependent upon endogenous opiates. Our results are particularly interesting in view of evidence for colocalization of $\beta$-endorphin and somatostatin in the pancreatic $D$ cell. ${ }^{2}$

Induction of hypoglycemia or recovery from the induced glucose nadir was unaffected by naloxone. Since opiates have been shown to directly mediate hepatic glucose production ${ }^{25}$ as well as insulin action, ${ }^{26}$ glucose homeostasis could have been maintained despite effects on SI secretion. Bright et $\mathrm{al}^{27}$ have shown that naloxone decreased recovery from hypoglycemia in humans without altering glucagon secretion. The dissimilarity of our findings and those of Bright et al may reflect different effects of opiates in different species. ${ }^{28,29}$

In summary, the $\alpha$ - and $\beta$-cell responses to arginine and the $\alpha$-cell response to hypoglycemia are not modulated by endogenous opiates. Somatostatin secretion following hypoglycemia-induced glucagon secretion is dependent upon endogenous opioid peptides. Opiates can modulate glucose metabolism independent of their effects on the endocrine pancreas. Thus, integrated studies of the hepatic, pancreatic, and gastrointestinal tract responses to physiologic stimuli will be necessary to elucidate the role(s) of endogenous opiates in maintaining glucose homeostasis.

\section{REFERENCES}

1. Grube D, Voight $\mathrm{KH}$, Weber E: Pancreatic glucagon cells containing endorphin-like immunoreactivity. Histochemistry 59:7579,1978

2. Watkins WB, Bruni JF, Yen SSC: $\beta$-endorphin and somatostatin in the pancreatic $D$-cell colocalization by immunocytochemistry. $\mathrm{J}$ Histochem Cytochem 28:1177-1174, 1980

3. Ipp E, Dobbs R, Unger RH: Morphine and $\beta$-endorphin influence the secretion of the endocrine pancreas. Nature 276:190191,1978

4. Green IC, Perrin D, Pedley KC, et al: Effect of enkephalin and morphine on insulin secretion from isolated rat islets. Diabetologia 19:158-161,1980

5. Kanter RA, Ensinck JW, Fujimoto WY: Disparate effects of enkephalin and morphine upon insulin and glucagon secretion by islet cell cultures. Diabetes 29:84-86, 1980

6. Reid RL, Yen SSC: $\beta$-endorphin stimulates the secretion of insulin and glucagon in humans. I Clin Endocrinol Metab 52:592594, 1981

7. Feldman M, Kiser RS, Unger RH, et al: Beta-endorphin and the endocrine pancreas. Studies in healthy and diabetic human beings. New Engl J Med 308:349-353, 1983

8. Schusdziarra V, Henrichs I, Holland A, et al: Evidence for an effect of exorphins on plasma insulin on glucagon levels in dogs. Diabetes 30:362-364, 1981

9. Palmer JP, Walter RM, Ensinck JW: Arginine stimulates acute phase of insulin and glucagon secretion. I: In normal man. Diabetes 24:735-740, 1975

10. Lundquist I, Fanskas R, Grodsky $\mathbf{G}$ : Interaction of calcium and glucose on glucagon secretion. Endocrinology 99:1304-1312, 1976

11. Faloona GR, Unger RH: Glucagon, in Jaffe BM, Behrman HR (eds): Methods of Hormone Radioimmunoassay. New York, Academic Press, 1974, pp 317-330

12. Yamada T, Marshak D, Basinger S, et al: Somatostatin-like immunoreactivity in the retina. DNAS (USA) 77:1691-1695, 1980

13. Seal A, Yamada T, Debas H, et al: Somatostatin -14 and - 28: Clearance and potency in gastric function in dogs. Am J Physiol 243:G97-G102, 1982

14. Green IC, Perrin D, Yaseen A, et al: Effect of dynorphin on insulin and somatostatin secretion, calcium uptake, and C-amp levels in isolated rat islets of Langerhans. Diabetes 32:685-690, 1983

15. Matsumura $M$, Fukushima $T$, Saito $H$, et al: In vivo and in vitro effects of $\beta$-endorphin on glucose metabolism in the rat. Horm Metab Res 16:27-31, 1984

16. Helman AM, Giraud P, Nicolaidis $S$, et al: Glucagon release after stimulation of the lateral hypothalamic area in rats: Predominant $\beta$-adrenergic transmission and involvement of endorphin pathways. Endocrinology 113:1-6, 1983

17. Bobbioni R, Jeanrenaud B: Effect of rat hypothalamic extract administration on insulin secretion in vivo. Endocrinology 110:631636,1982

18. Moltz JH, Dobbs RE, McCann SM, et al: Effects of hypothalamic factors on insulin and glucagon release from islets of Langerhans. Endocrinology 101:196-202, 1976

19. Morley JE, Baranetsky NG, Wingert TD, et al: Endocrine 
effects of naloxone-induced opiate receptor blockade. J Clin Endocrinol Metab 50:251-257, 1980

20. Glaser B, Vinik AI, Valtysson G, et al: Truncal vagotomy abolishes the somatostatin response to insulin-induced hypoglycemia in man. J Clin Fndocrinol Metab 52:823 825, 1983

21. Schusdziarra V, Schick R, De La Fuente A, et al: Effect of $\beta$-casomorphins on somatostatin release in dogs. Endocrinology 112:1948-1951, 1983

22. Morley JE, Levine AS, Yamada $T$, et al: Function of exorphins on gastrointestinal function, hormonal release and appetite. Gastroenterology 84:1517-1523, 1983

23. Hermansen K: Enkephalins and the secretion of pancreatic somatostatin and insulin in the dog: Studies in vitro. Endocrinology 113:1149-1154, 1983

24. Taborsky GJ, Ensinck JW: Contribution of the pancreas to circulating somatostatin-like immunoreactivity in the normal dog. $\mathbf{J}$ Clin Invest (USA) 73:216-223, 1984

25 . Radosevich PM, Williams PE, McRae JR, et al: $\beta$-endorphin inhibits glucose production in the conscious dogs. J Clin Invest (USA) 73:1237-1241, 1984

26. Werther GA, Joffe S, Artral R, et al: Opiates modulate insulin action in vivo in dogs. Diabetologia 26:65 69, 1984

27. Bright GM, Kaiser DL, Rogol AD, et al: Naloxone attenuates recovery from insulin-induced hypoglycemia in normal man. J Clin Endocrinol Metab 157:213-216, 1983

28. Mason JS, Heber D: Endogenous opioids modulate insulin secretion in flushing noninsulin-dependent diabetics. J Clin Endocrinol Metab 54:693-697, 1982

29. Rudman D, Berry CJ, Reideburg CH, et al: Effects of opiate peptides and opiate alkaloids on insulin secretion in the rabbit. Endocrinology 112:1702-1710, 1983 